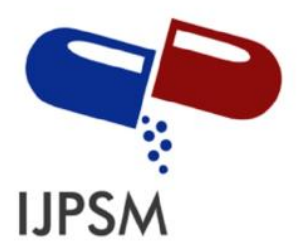

Aruna V et al, Int. Journal of Pharmaceutical Sciences and Medicine (IJPSM), Vol.5 Issue. 12, December- 2020, pg. 23-34

ISSN: 2519-9889

Impact Factor: $\mathbf{3 . 4 2 6}$

\title{
Methods to Enhance Primary Immune Surveillance under Hypoxia
}

\author{
Aruna V*; Amruthavalli GV; Gayathri R
}

Dr. JRK's Research \& Pharmaceuticals Pvt. Ltd

No. 18 \& 19, Perumal Koil Street, Kunrathur, Chennai- 600069

DOI: 10.47760/ijpsm.2020.v05i12.006

\author{
Corresponding Author, \\ Aruna V, M.Pharm \\ Email id-aruna_v@jrkresearch.com, \\ research@jrkresearch.com \\ Mobile no- 9566165310
}

Abstract: The study was planned with a hypothesis that hypoxia would adversely impair the phagocytic ability of phagocyte and the treatment option should be to boost the phagocytic ability under such situation. The phagocytes were cultured in hypoxic condition and were challenged with an array of antigens under the coded formulation treatment. The findings showed that hypoxia would not only damage the cell viability but also would affect the phagocytic ability. The coded drug showed enormous potential repairing the damage due to hypoxia. Details are presented in the paper.

Keywords: Hypoxia, phagocytes, herbal immune boosters, pneumocytes, COVID-19, immunity

\section{Introduction}

Primary immune surveillance mechanism is a part of innate immunity; comprised of macrophages, monocytes, neutrophils etc. The innate immunity is the entry security system for any pathogen and unless and until the pathogen tricks the security line or weakens the same, it cannot enter the host system. Despite adequate security measures some pathogens may find their way into the human system. Those fortunate microbes would never limit their fortune to itself but further they weakens the shackle of immune defense for the entry of subsequent generation of pathogens. ${ }^{1,2,3}$ 


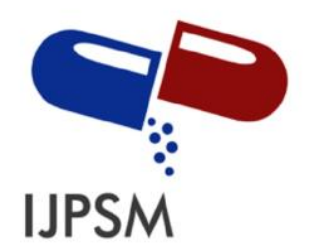

Aruna V et al, Int. Journal of Pharmaceutical Sciences and Medicine (IJPSM), Vol.5 Issue. 12, December- 2020, pg. 23-34

ISSN: 2519-9889

Impact Factor: $\mathbf{3 . 4 2 6}$

Many pathogens instead of directly weakening the primary immune surveillance would try to harm/damage pneumocytes which aids in gas exchange especially the oxygen. When the oxygen level diminishes in the blood, the primary immune surveillance cells would move towards causing functional and or physiological atrophy of the lungs. 4, 5, 6

The primary immune surveillance cells therefore set to lose their phagocytic ability during hypoxia. Protecting and or promoting the ability of innate immune defense mechanism under hypoxia condition is therefore necessary. ${ }^{7}$

The herbal immune boosters have been proven to have enormous value in offering protection to the host from pathogens. The adaptive immunity is unlikely to be elicited or evoked to a higher state of performance by immune boosters. ${ }^{8,9,10}$

To understand the possible immune boosting effect of a poly herbal preparation on phagocytes shocked with hypoxic condition and studied. Although the study findings are only directional and indicative, but the medical significance will be far reaching if further research validation and clinical trial are conducted. Details are presented in the paper.

\section{Materials and Methods}

\section{Details of the Poly Herbal Preparation (PHP)}

The PHP is a liposomal formulation made with the fixed oil of Sesame indicum and is composed of the extracts of Indigofera aspalathoides, Celastrus paniculatus, Corallocarpus epigaeus, Cinnamomum camphora, Solanum trilobatum

\section{Experimental Details}

The study was planned in two phases such as generalized effect of a polyherbal preparation (PHP) on fibroblast and macrophage grown under normoxic and hypoxic condition. To determine the effect on the above cells we employed MTT assay. 0.5, 1, 5, 10 and 15 $\mu \mathrm{g} / \mathrm{ml}$ 


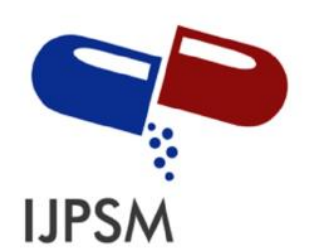

Aruna V et al, Int. Journal of Pharmaceutical Sciences and Medicine (IJPSM), Vol.5 Issue. 12, December- 2020, pg. 23-34

ISSN: 2519-9889

Impact Factor: $\mathbf{3 . 4 2 6}$

concentration of PHP in cell culture medium and then the percentage of cell viability was tested using MTT dye. ${ }^{11}$

The second experiment was designed to study the effect of PHP on the phagocytic ability of macrophages under hypoxic condition against a battery of antigens such as S.aureus, E.coli, C.albicans, A.fumigatus. The antigens were opsonized and then exposed to the phagocytes and studied the percentage of phagocytes in the total lot participated in the process of phagocytosis and the number of antigens got ingested. For an overall understanding non-opsonized antigens were also used, and were exposed to the phagocytes grown in hypoxic condition. Direct microscopy and tryphan blue dye exclusion assay were performed to determine the above.

\section{Effect of PHP on the viability of fibroblast under hypoxic condition}

The fibroblast when grown under normal condition (without PHP) showed only 2\% death whereas when the cells were exposed to higher concentration of $\mathrm{Co} 2(10 \%), 5 \%$ above the tissue culture requirement resulted in $70 \%$ death of the cells due to hypoxic shock.

When the fibroblast cells were exposed to hypoxic condition (10\% Co2) along with PHP treatment at varying concentrations showed a dose dependent protection to the cells from hypoxic shock. The total \% of cell death from 70 under hypoxic condition without PHP had reduced to $22 \%$ with PHP intervention. Table- 1

\begin{tabular}{|c|c|c|c|c|c|}
\hline \multirow[t]{2}{*}{ Treatment } & \multicolumn{5}{|c|}{ Concentration of PHP $(\mu \mathrm{g} / \mathrm{ml})$ and $\%$ of cell death } \\
\hline & 0.5 & 1 & 5 & 10 & 15 \\
\hline Untreated & \multicolumn{5}{|c|}{2} \\
\hline Cells under hypoxic condition & \multicolumn{5}{|c|}{70} \\
\hline PHP treatment & 2 & 1.5 & 2 & 5 & 7 \\
\hline $\begin{array}{l}\text { Cells under hypoxic condition treated } \\
\text { with PHP }\end{array}$ & 58 & 49 & 40 & 37 & 22 \\
\hline
\end{tabular}




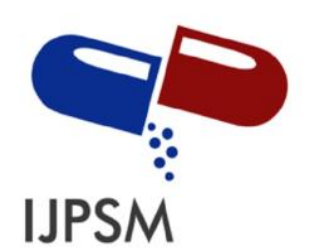

Aruna V et al, Int. Journal of Pharmaceutical Sciences and Medicine (IJPSM), Vol.5 Issue. 12, December- 2020, pg. 23-34

ISSN: 2519-9889

Impact Factor: 3.426

\section{Effect of PHP on the viability of phagocytes under hypoxic condition}

The phagocytes when grown under normal condition (without PHP) showed only 1\% death whereas when the cells were exposed to higher concentration of $\mathrm{Co} 2(10 \%), 5 \%$ above the tissue culture requirement resulted in $28 \%$ death of the cells due to hypoxic shock.

When the fibroblast cells were exposed to hypoxic condition (10\% Co2) along with PHP treatment at varying concentrations showed a dose dependent protection to the cells from hypoxic shock. The total \% of cell death from 28 under hypoxic condition without PHP had reduced to 3\% with PHP intervention. Table- 2

\begin{tabular}{|c|c|c|c|c|c|}
\hline \multirow[t]{2}{*}{ Treatment } & \multicolumn{5}{|c|}{ Concentration of PHP $(\mu \mathrm{g} / \mathrm{ml})$ and $\%$ of cell death } \\
\hline & 0.5 & 1 & 5 & 10 & 15 \\
\hline Untreated & \multicolumn{5}{|c|}{1} \\
\hline Cells under hypoxic condition & \multicolumn{5}{|c|}{28} \\
\hline PHP herbal drops treatment & 2 & 5 & 7 & 11 & 13 \\
\hline $\begin{array}{l}\text { Cells under hypoxic condition treated } \\
\text { with PHP }\end{array}$ & 21 & 17 & 13 & 7 & 3 \\
\hline
\end{tabular}

\section{Effect of PHP on phagocytosis under hypoxia against various antigens}

\section{Staphylococcus aureus}

The phagocytic ability of phagocytes in control (untreated) was $70.1 \%$ and the same ability diminished to $13.6 \%$ when the phagocytes were stressed with hypoxic condition. When the phagocytes were grown with PHP and stressed with hypoxic shock showed an increased phagocytic ability of $90.5 \%$ from untreated value of $13.6 \%$.

The phagocytic ability against opsonized and non-opsonized pathogens remains the same due to PHP treatment. 


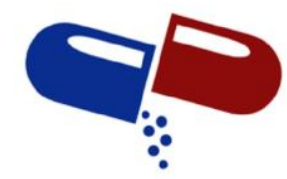

IJPSM

Aruna V et al, Int. Journal of Pharmaceutical Sciences and Medicine (IJPSM),

Vol.5 Issue. 12, December- 2020, pg. 23-34

ISSN: 2519-9889

Impact Factor: 3.426

\begin{tabular}{|c|c|c|c|c|c|c|c|}
\hline Treatment & $\begin{array}{l}\text { Conc } \\
\text { in } \\
\mu \mathrm{g} / \mathrm{ml}\end{array}$ & $\begin{array}{l}\text { Total no of } \\
\text { phagocytes }\end{array}$ & $\begin{array}{c}\text { No. of } \\
\text { phagocytized } \\
\text { cells }\end{array}$ & $\begin{array}{c}\text { No of } \\
\text { ingested } \\
\text { antigen }\end{array}$ & $\begin{array}{l}\text { Improvement } \\
\text { in Phagocytic } \\
\text { ability (\%) }\end{array}$ & $\begin{array}{c}\text { No } \\
\text { of } \\
\text { cells } \\
\text { used }\end{array}$ & $\begin{array}{c}\% \\
\text { susceptibility }\end{array}$ \\
\hline \multicolumn{8}{|c|}{ Opsonized S.aureus cells used as antigen } \\
\hline Control & - & 171 & 120 & 80 & 70.1 & & 26.6 \\
\hline $\begin{array}{c}\text { Cells under } \\
\text { hypoxia }\end{array}$ & - & 132 & 18 & 31 & 13.6 & & 10.2 \\
\hline $\begin{array}{c}\text { PHP } \\
\text { treatment }\end{array}$ & 5 & 180 & 165 & 238 & 91.6 & & 79.3 \\
\hline $\begin{array}{c}\text { Cells under } \\
\text { hypoxia } \\
\text { +PHP }\end{array}$ & 5 & 179 & 162 & 191 & 90.5 & 300 & 63.6 \\
\hline \multicolumn{8}{|c|}{ Non- opsonized S.aureus cells used as antigen } \\
\hline Control & - & 168 & 92 & 52 & 54.7 & & 17.3 \\
\hline $\begin{array}{c}\text { Cells under } \\
\text { hypoxia }\end{array}$ & & 141 & 7 & 21 & 4.9 & & 7 \\
\hline $\begin{array}{c}\text { PHP } \\
\text { treatment }\end{array}$ & 5 & 174 & 150 & 211 & 86.2 & & 70.3 \\
\hline $\begin{array}{c}\text { Cells under } \\
\text { hypoxia } \\
\text { +PHP }\end{array}$ & 5 & 139 & 120 & 182 & 86.3 & 300 & 60.6 \\
\hline
\end{tabular}




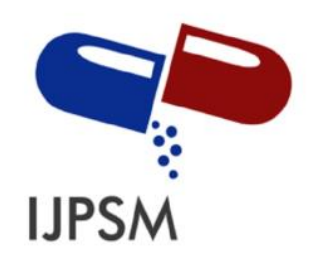

Aruna V et al, Int. Journal of Pharmaceutical Sciences and Medicine (IJPSM), Vol.5 Issue. 12, December- 2020, pg. 23-34

ISSN: 2519-9889 Impact Factor: $\mathbf{3 . 4 2 6}$

$\underline{\text { E. coli }}$

The phagocytic ability of phagocytes in control (untreated) was $41.7 \%$ and the same ability diminished to $14.1 \%$ when the phagocytes were stressed with hypoxic condition. When the phagocytes were grown with PHP and stressed with hypoxic shock showed an increased phagocytic ability of $80.5 \%$ from untreated value of $14.1 \%$.

The phagocytic ability against opsonized and non-opsonized pathogens remains the same due to PHP treatment.

\begin{tabular}{|c|c|c|c|c|c|c|c|}
\hline Treatment & $\begin{array}{c}\text { Conc } \\
\text { in } \\
\mu \mathrm{g} / \mathrm{ml}\end{array}$ & $\begin{array}{l}\text { Total no of } \\
\text { phagocytes }\end{array}$ & $\begin{array}{c}\text { No. of } \\
\text { ingested } \\
\text { phagocytosis }\end{array}$ & $\begin{array}{c}\text { No of } \\
\text { ingested } \\
\text { cells }\end{array}$ & $\begin{array}{c}\text { Improvement } \\
\text { in Phagocytic } \\
\text { ability (\%) }\end{array}$ & $\begin{array}{c}\text { No } \\
\text { of } \\
\text { cells } \\
\text { used }\end{array}$ & $\begin{array}{c}\% \\
\text { susceptibility }\end{array}$ \\
\hline \multicolumn{8}{|c|}{ Opsonized E.coli used as antigen } \\
\hline Control & - & 211 & 88 & 140 & 41.7 & \multirow[t]{4}{*}{300} & 46.6 \\
\hline $\begin{array}{l}\text { Cells under } \\
\text { hypoxia }\end{array}$ & - & 170 & 24 & 51 & 14.1 & & 17 \\
\hline PHPtreatment & 5 & 218 & 194 & 208 & 88.9 & & 69.3 \\
\hline $\begin{array}{c}\text { Cells under } \\
\text { hypoxia +PHP }\end{array}$ & 5 & 216 & 174 & 191 & 80.5 & & 63.6 \\
\hline \multicolumn{8}{|c|}{ Non- opsonized E.coli used as antigen } \\
\hline Control & - & 181 & 54 & 88 & 29.8 & & 29.3 \\
\hline $\begin{array}{l}\text { Cells under } \\
\text { hypoxia }\end{array}$ & & 134 & 5 & 41 & 3.7 & & 13.6 \\
\hline PHP treatment & 5 & 198 & 160 & 201 & 80.8 & & 67 \\
\hline $\begin{array}{c}\text { Cells under } \\
\text { hypoxia +PHP }\end{array}$ & 5 & 128 & 94 & 108 & 73.4 & 300 & 36 \\
\hline
\end{tabular}




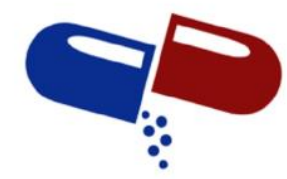

IJPSM

Aruna V et al, Int. Journal of Pharmaceutical Sciences and Medicine (IJPSM), Vol.5 Issue. 12, December- 2020, pg. 23-34

ISSN: 2519-9889

Impact Factor: 3.426

\section{C.albicans}

The phagocytic ability of phagocytes in control (untreated) was $21.1 \%$ and the same ability diminished to $4.4 \%$ when the phagocytes were stressed with hypoxic condition. When the phagocytes were grown with PHP and stressed with hypoxic shock showed an increased phagocytic ability of $90.4 \%$ from untreated value of $4.4 \%$.

\begin{tabular}{|c|c|c|c|c|c|c|c|}
\hline Treatment & $\begin{array}{l}\text { Conc } \\
\text { in } \\
\mu \mathrm{g} / \mathrm{ml}\end{array}$ & $\begin{array}{l}\text { Total no of } \\
\text { phagocytes }\end{array}$ & $\begin{array}{c}\text { No. of } \\
\text { ingested } \\
\text { phagocytosis }\end{array}$ & $\begin{array}{c}\text { No of } \\
\text { ingested } \\
\text { cells }\end{array}$ & $\begin{array}{c}\text { Improvement } \\
\text { in Phagocytic } \\
\text { ability (\%) }\end{array}$ & $\begin{array}{c}\text { No } \\
\text { of } \\
\text { cells } \\
\text { used }\end{array}$ & $\begin{array}{c}\% \\
\text { susceptibility }\end{array}$ \\
\hline \multicolumn{8}{|c|}{ Opsonized Candida albicans used as antigen } \\
\hline Control & - & 199 & 42 & 101 & 21.1 & \multirow{4}{*}{300} & 33.6 \\
\hline $\begin{array}{l}\text { Cells under } \\
\text { hypoxia }\end{array}$ & - & 180 & 8 & 61 & 4.4 & & 20.3 \\
\hline $\begin{array}{c}\text { PHP } \\
\text { treatment }\end{array}$ & 5 & 200 & 189 & 213 & 94.5 & & 71 \\
\hline $\begin{array}{l}\text { Cells under } \\
\text { hypoxia } \\
\text { +PHP }\end{array}$ & 5 & 178 & 161 & 199 & 90.4 & & 66.3 \\
\hline \multicolumn{8}{|c|}{ Non- opsonized Candida albicans used as antigen } \\
\hline Control & - & 174 & 42 & 102 & 24.1 & \multirow{4}{*}{300} & 34 \\
\hline $\begin{array}{l}\text { Cells under } \\
\text { hypoxia }\end{array}$ & & 154 & 7 & 38 & 4.5 & & 12.6 \\
\hline $\begin{array}{c}\text { PHP } \\
\text { treatment }\end{array}$ & 5 & 205 & 192 & 213 & 93.6 & & 71 \\
\hline $\begin{array}{l}\text { Cells under } \\
\text { hypoxia } \\
\text { +PHP }\end{array}$ & 5 & 168 & 89 & 194 & 52.9 & & 64.6 \\
\hline
\end{tabular}




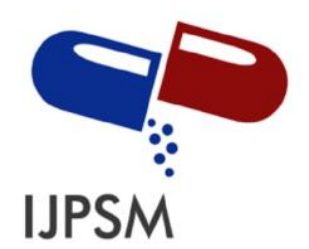

Aruna V et al, Int. Journal of Pharmaceutical Sciences and Medicine (IJPSM), Vol.5 Issue. 12, December- 2020, pg. 23-34

ISSN: 2519-9889 Impact Factor: 3.426

Aspergillus fumigatus

The phagocytic ability of phagocytes in control (untreated) was $25 \%$ and the same ability diminished to $6.8 \%$ when the phagocytes were stressed with hypoxic condition. When the phagocytes were grown with PHP and stressed with hypoxic shock showed an increased phagocytic ability of $93.8 \%$ from untreated value of $6.8 \%$. The phagocytic ability against opsonized and non-opsonized pathogens remains the same due to PHP treatment.

\begin{tabular}{|c|c|c|c|c|c|c|c|}
\hline Treatment & $\begin{array}{l}\text { Conc } \\
\text { in } \\
\mu \mathrm{g} / \mathrm{ml}\end{array}$ & $\begin{array}{l}\text { Total no of } \\
\text { phagocytes }\end{array}$ & $\begin{array}{c}\text { No. of } \\
\text { ingested } \\
\text { phagocytosis }\end{array}$ & $\begin{array}{c}\text { No of } \\
\text { ingested } \\
\text { cells }\end{array}$ & $\begin{array}{l}\text { Improvement } \\
\text { in Phagocytic } \\
\text { ability (\%) }\end{array}$ & $\begin{array}{c}\text { No } \\
\text { of } \\
\text { cells } \\
\text { used }\end{array}$ & $\begin{array}{c}\% \\
\text { susceptibility }\end{array}$ \\
\hline \multicolumn{8}{|c|}{ Opsonized Aspergillus fumigatus used as antigen } \\
\hline Control & - & 152 & 38 & 140 & 25 & \multirow{4}{*}{300} & 46.6 \\
\hline $\begin{array}{c}\text { Cells under } \\
\text { hypoxia }\end{array}$ & - & 161 & 11 & 44 & 6.8 & & 14.6 \\
\hline $\begin{array}{c}\text { PHP } \\
\text { treatment }\end{array}$ & 5 & 180 & 171 & 224 & 95 & & 74.6 \\
\hline $\begin{array}{c}\text { Cells under } \\
\text { hypoxia } \\
\text { +PHP }\end{array}$ & 5 & 179 & 168 & 213 & 93.8 & & 71 \\
\hline \multicolumn{8}{|c|}{ Non- opsonized Aspergillus fumigatus used as antigen } \\
\hline Control & - & 162 & 35 & 113 & 21.6 & \multirow{4}{*}{300} & 36.6 \\
\hline $\begin{array}{c}\text { Cells under } \\
\text { hypoxia }\end{array}$ & & 171 & 18 & 28 & 10.5 & & 9.3 \\
\hline PHP & 5 & 192 & 180 & 230 & 93.7 & & 76.6 \\
\hline $\begin{array}{c}\text { Cells under } \\
\text { hypoxia } \\
\text { +PHP }\end{array}$ & 5 & 170 & 152 & 211 & 89.1 & & 70.3 \\
\hline
\end{tabular}




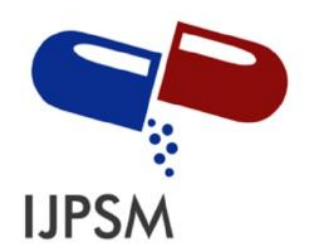

Aruna V et al, Int. Journal of Pharmaceutical Sciences and Medicine (IJPSM), Vol.5 Issue. 12, December- 2020, pg. 23-34

ISSN: 2519-9889

Impact Factor: 3.426

\section{Discussion}

Although the primary immune surveillance cells such as macrophages, monocytes and neutrophils play an important role in the entry level defense of the host but still certain pathogens can escape the early gate point. Many pathogens that made such tricks and could enter into human system through the respiratory gateway often navigate the lungs as their final destination.

Often the pathogens that enter the lungs would damage the pneumocytes or alveoli in the lungs which results in poor gas exchange especially the oxygen in the blood. Such condition is called hypoxia. The hypoxic condition although leads to organ level complication and even death but initially would impair the phagocytic ability of phagocytes. As a result of the above hypoxic condition, free entry being achieved by the pathogen. ${ }^{11,12}$

Further the hypoxic condition would not only reduce the cell viability (survival) but also the functional ability of the immune surveillance cells such as phagocytes. Therefore achieving the required oxygen saturation level is necessary but at the same time giving a kick to the phagocytes to enhance their phagocytic ability is also necessary.

Herbal immune boosters are gaining importance in healthcare system post COVID-19 pandemic. ${ }^{13,14}$ The herbal immune boosters are unlikely to play any role in boosting the adaptive or acquired immunity of the host. Therefore we presumed that the herbal immune boosters may enhance the primary immune surveillance mechanism. However such immune boosters would also enhance the antigen engulfing property of the phagocytes under hypoxic condition is not known. 


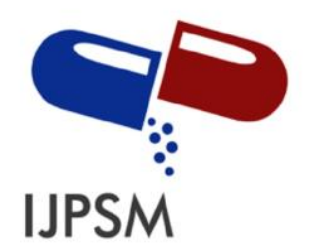

Aruna V et al, Int. Journal of Pharmaceutical Sciences and Medicine (IJPSM), Vol.5 Issue. 12, December- 2020, pg. 23-34

ISSN: 2519-9889

Impact Factor: $\mathbf{3 . 4 2 6}$

When the fibroblast was given hypoxic shock with and without PHP we found that PHP significantly protected cells from death due to hypoxic shock. Similarly the protective effect of PHP on macrophages was also significant when the cells were grown in hypoxic condition.

We have used four different types of both opsonized and non-opsonized antigens such as S.aureus, E.coli, C.albicans and A.fumigatus. The ability of phagocytes under hypoxic condition treated with PHP was significant when compared to PHP non-treated phagocytes under hypoxic condition.

Our findings clearly suggest that PHP not only prevent the possible cell death due to hypoxic shock but also enhances the phagocytic ability of phagocytes. We did not find any great difference in the susceptibility of both the opsonized and non-opsonized antigens may be because of PHP treatment to the phagocytes. The PHP may be partly paralyzing the antigens.

In our earlier studies we have established a weak anti-microbial activity of various herbs in the PHP against broad spectrum of microbes such as bacteria and fungi (yeast and mold) included in the study.

Perhaps the above anti-microbial activity would have enhanced the susceptibility of the antigen coupled with the immune boosting performance of phagocytes. How and the underlying mechanism behind the protection PHP has offered to the phagocytes is difficult to explain by our present study but the existence of such possibility warrant further study.

The COVID-19 pandemic has clearly warned the medical fraternity and humanity as a whole that the respiratory pathogen, lung damage and hypoxia are going to be the principal clinical conditions going to cause mortality. The herbal immune boosters considering their ability to boost the primary immune surveillance cells must be used for preventive and paramedical purposes than as treatment drugs like the allopathic preparations. 


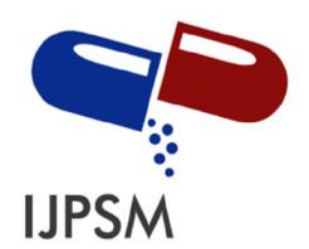

Aruna V et al, Int. Journal of Pharmaceutical Sciences and Medicine (IJPSM), Vol.5 Issue. 12, December- 2020, pg. 23-34

ISSN: 2519-9889

Impact Factor: $\mathbf{3 . 4 2 6}$

Herbal therapy should be meant more for prevention than for cure. Even the COVID-19 pandemic warrants preventive measures more than treatment such as use of mask, following social distancing and frequent hand wash.

Findings of our study evidently points towards the existence of some degree of science in herbal immune boosters especially during hypoxic condition.

\section{References}

[1]. Gert Jan Fleuren, Peter J.K. Kuppen, in Encyclopedia of Immunology (Second Edition), 1998

[2]. Schmid, D., Münz, C. Immune surveillance of intracellular pathogens via autophagy. Cell Death Differ 12, 1519-1527 (2005). https://doi.org/10.1038/sj.cdd.4401727

[3]. Ostrand-Rosenberg S. Immune surveillance: a balance between protumor and antitumor immunity. Curr Opin Genet Dev. 2008;18(1):11-18. doi:10.1016/j.gde.2007.12.007

[4]. Gu J, Korteweg C. Pathology and pathogenesis of severe acute respiratory syndrome. Am J Pathol. 2007;170(4):11361147. doi:10.2353/ajpath.2007.061088

[5]. He Z, Zhao C, Dong Q, Zhuang H, Song S, Peng G, Dwyer DE. Effects of severe acute respiratory syndrome (SARS) coronavirus infection on peripheral blood lymphocytes and their subsets. Int J Infect Dis. 2005;9:323-330

[6]. Guan Y, Zheng BJ, He YQ, Liu XL, Zhuang ZX, Cheung CL, Luo SW, Li PH, Zhang LJ, Guan YJ, Butt KM, Wong KL, Chan KW, Lim W, Shortridge KF, Yuen KY, Peiris JS, Poon LL. Isolation and characterization of viruses related to the SARS coronavirus from animals in southern China. Science. 2003;302:276-278.

[7]. Nizet V, Johnson RS. Interdependence of hypoxic and innate immune responses. Nat Rev Immunol. 2009;9(9):609617. doi:10.1038/nri2607

[8]. Khanna K, Kohli SK, Kaur R, et al. Herbal immune-boosters: Substantial warriors of pandemic Covid-19 battle [published online ahead of print, 2020 Oct 3]. Phytomedicine. 2020;153361. doi:10.1016/j.phymed.2020.153361

[9]. Ahmad A., Rehman M.U., Alkharfy K.M. An alternative approach to minimize the risk of coronavirus (Covid-19) and similar infections. Eur. Rev. Med. Pharm. Sci. 2020;24(7):4030-4034.

[10].Bouchentouf S., Missoum N. Identification of compounds from Nigella Sativa as new potential inhibitors of 2019 novel coronavirus (Covid-19): molecular docking study. ChemRxiv. 2020 doi: 10.26434/chemrxiv.12055716.v1. 


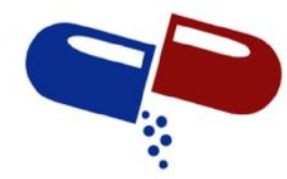

\section{IJPSM}

Aruna V et al, Int. Journal of Pharmaceutical Sciences and Medicine (IJPSM), Vol.5 Issue. 12, December- 2020, pg. 23-34

ISSN: 2519-9889

Impact Factor: 3.426

[11].Sarkar M, Niranjan N, Banyal PK. Mechanisms of hypoxemia [published correction appears in Lung India. 2017 MarApr;34(2):220]. Lung India. 2017;34(1):47-60. doi:10.4103/0970-2113.197116

[12].Michiels C.Physiological and pathological responses to hypoxia. Am J Pathol. 2004;164(6):1875-1882. doi:10.1016/S0002-9440(10)63747-9

[13].https://www.thehindu.com/sci-tech/health/coronavirus-immunity-boosters-can-turn-harmful/article32793667.ece

[14].Muhammad Sajid Arshad Urooj Khan Anam Sadiq Waseem Khalid Muhammad Hussain Ammara Yasmeen Zubia Asghar Hafiza Rehana. Coronavirus disease (COVID-19) and immunity booster green foods: A mini review. Food science \& nutrition. 2020;8 (8); 3971-3976 